\title{
An advanced approach for catchment delineation and water balance modelling within wetlands and floodplains
}

\author{
S. Krause ${ }^{1}$ and A. Bronstert ${ }^{2}$ \\ ${ }^{1}$ Centre for Sustainable Water Management, Lancaster Environment Centre, LA1 4YQ Lancaster, UK \\ ${ }^{2}$ Geoecology Institute, Department for Hydrology and Climatology, Potsdam University, PO-Box 601553, 14415 Potsdam, \\ Germany
}

Received: 7 January 2005 - Revised: 1 August 2005 - Accepted: 1 September 2005 - Published: 16 December 2005

\begin{abstract}
Water balance of wetlands within lowland floodplains is strongly influenced by the temporally variable spatial extent of the interactions between groundwater and surface water. A robust algorithm will be introduced which makes it possible to delineate the interaction zone between the lowland river and the floodplain. This interaction zone is specified as the "Direct Catchment" which is defined by the part of the connected floodplain in which wetland water balance is mainly affected by the surface water dynamics of the adjacent river. The delineation algorithm is based on transfer functions which were assessed by local simulation results of the integrated water balance and nutrient dynamics model IWAN. The transfer functions are further determined by mean annual groundwater depths and by simulated groundwater dynamics. They are controlled by simulation results of the maximal transversal extent of surface water influence on groundwater stages. The regionalisation of the developed delineation algorithm leads to the specification of the maximal extent of groundwater - surface water - interaction processes along the river. By application of this approach to the Havel River basin, located within lowlands of Northeaster Germany, it was possible to specify a $998.1 \mathrm{~km}^{2}$ part of the floodplain which is directly connected with the surface waters and thus called the "Direct Catchment" of the Havel river. The IWAN model was applied to simulate the water balance of the floodplain. The simulation results prove the tight interaction between river and floodplain. It is shown that the spatially and temporally variable influences of the connected floodplain on the river discharge were only important during low discharge in summer.
\end{abstract}

\section{Introduction}

For successful simulation of water balance and nutrient dynamics within river floodplains an adequate reflection of the runoff generation and water balance processes is necessary. Thus, also groundwater - surface water - interactions have to be implemented into an advanced model concept (Krause 2004a, c; Sophocleous, 2002).

The identification and consistent classification of model boundaries are fundamental demands for correct and unique solutions of the descriptive equations of any model. For an adequate reflection of water balance and nutrient dynamic processes information about the extent of the model area, the model geometry as well as the conditions on the model boundaries is required. In hydrological sciences distributed mesoscale models based on raster approaches as well as on hydrotopes are usually applied to catchment and subcatchment units.

Delineation of watersheds within lowland floodplains based on automatic digital terrain analysis algorithms is often not possible because a minimal extent of topographical heterogeneity is required (topographic gradients are too small compared to the resolution of the DEM).

Furthermore wetland water balance is strongly affected by groundwater processes as well as by the interactions between groundwater and surface water. Therefore the consideration of the surface watershed alone is not suitable for the characterisation of process boundaries.

The spatial extent of the delineated surface watershed does often not match with the groundwater catchment boundaries. A further problem is caused by the interaction between river and floodplain. Runoff, which is generated within the floodplain, discharges into the main river via tributaries but also by the way of interactions between groundwater and surface water (Fig. 1). 


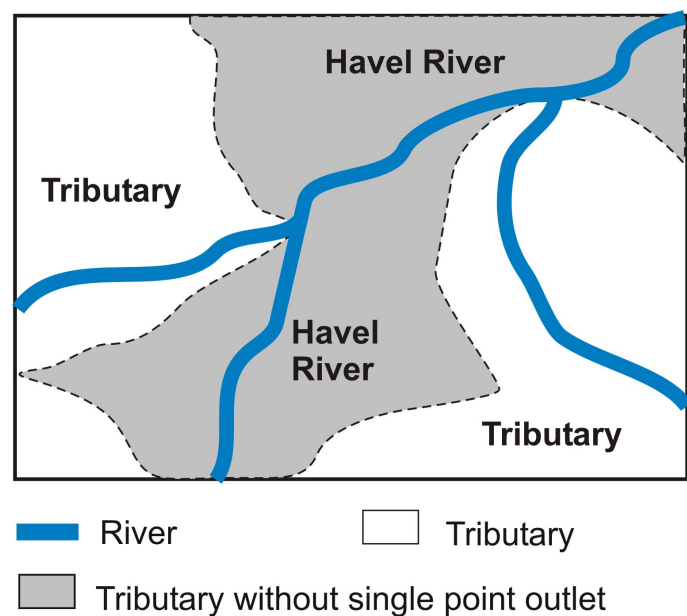

Fig. 1. Floodplain area with tributaries (white) and areas without single point outlets which are characterised by spatial interactions with the river (grey).

For adequate reflection of the spatial distribution of water balance and nutrient dynamic processes within the floodplain, the "Direct Catchment" of the corresponding river has to be delineated. This "Direct Catchment" is defined as part of the floodplain in which the water balance is mainly influenced by surface water dynamics (Fig. 2).

The simulation of the specific hydrological characteristics of floodplains as well as the adequate reflection of water balance and groundwater processes is possible using the IWAN model (Krause, 2004a, c), which enables the integrated modelling of water balance and groundwater dynamics of floodplains. This model also reflects interaction processes between the groundwater of the floodplain and the surface water.

\section{Materials and methods}

\subsection{The IWAN model}

The IWAN model is based on the coupling of the deterministic distributed hydrological model WASIM-ETH (Niehoff, 2002; Schulla, 1997) with the numerical, finite difference based groundwater model MODFLOW (Chiang, 2001; Harbaugh, 1996a, b). WASIM-ETH is used for the simulation of runoff generation as well as water balance within the unsaturated zone whereas MODFLOW simulates the lateral groundwater flow and the interaction with the surface water. The water balance routines of the IWAN model were calibrated and successfully validated for several subcatchments within the Lower Havel floodplain (Krause, 2004a, b). The applicability of the model was tested by event based simulations as well as by perennial simulations of water balance including the simulation of landuse change scenarios (Krause, $2004 b, c)$.

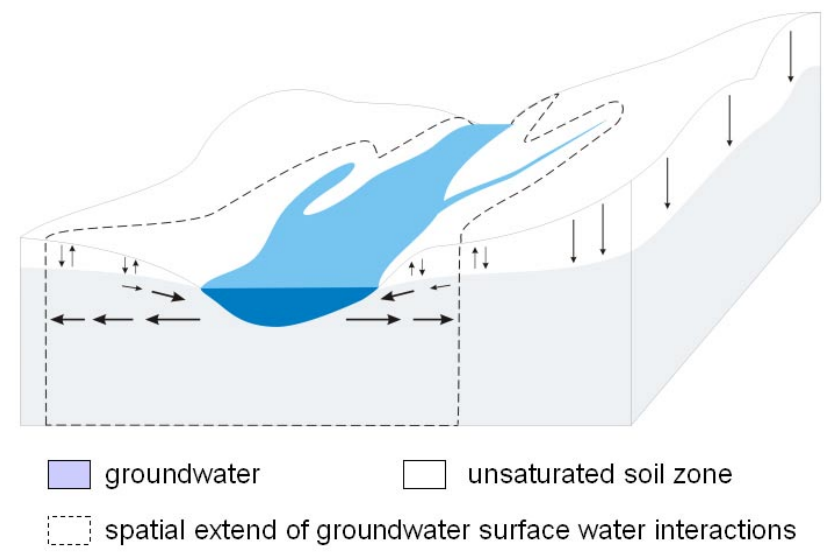

Fig. 2. The spatial extent of the "Direct Catchment" as the zone within the floodplain which is characterised by the interaction between groundwater and surface water.

\subsection{Delineation of the "Direct Catchment"}

The presented approach assumes that the delineation of the direct interaction zone between river and floodplain can be achieved by the analysis of the spatial extent of the dynamic interaction processes between groundwater and surface water. The delineation algorithm (Fig. 3) is based on the analysis of geomorphological, topographical and hydrological characteristics of intensively investigated subcatchments within the floodplain (Krause, 2004c).

In a first step of the delineation algorithm (Fig. 3) the digital elevation model (spatial resolution of $50 \mathrm{~m}$, vertical resolution of $0.1 \mathrm{~m}$ (mean vertical error $+/-2 \mathrm{~m}$ ) was improved by topographical maps (1:10000), surveying and the analysis of laser scan data at some areas. These corrections were necessary because of an insufficient quality of the original DEM data which was mainly caused by digitalisation errors while its generation as well as by compaction of organic soils due to drainage and degradation. In a second step surface watersheds within intensively studied areas were delineated by digital relief analysis (Fig. 3). Because surface watersheds and subsurface watersheds usually differ in lowland areas, delineation of surface watersheds only is not sufficient for specification of interaction zones within the intensively investigated areas. Thus, the consideration of further floodplain characteristics became necessary to identify the "Direct Catchment" area.

Experimental investigations within the Havel River basin prove that annual groundwater stage dynamics of the shallow groundwater of the floodplain were mainly determined by the influence of surface water stage dynamics (Krause, 2004c). A general decrease of groundwater stage dynamics with increasing distance to the main river as well as relatively low groundwater depths within the surface water influenced floodplain and higher groundwater depths within the more peripheral moraine regions at the floodplain boundary could be detected (Krause, 2004a, c). Thus, the analysis of groundwater depth distribution is an appropriate strategy for 


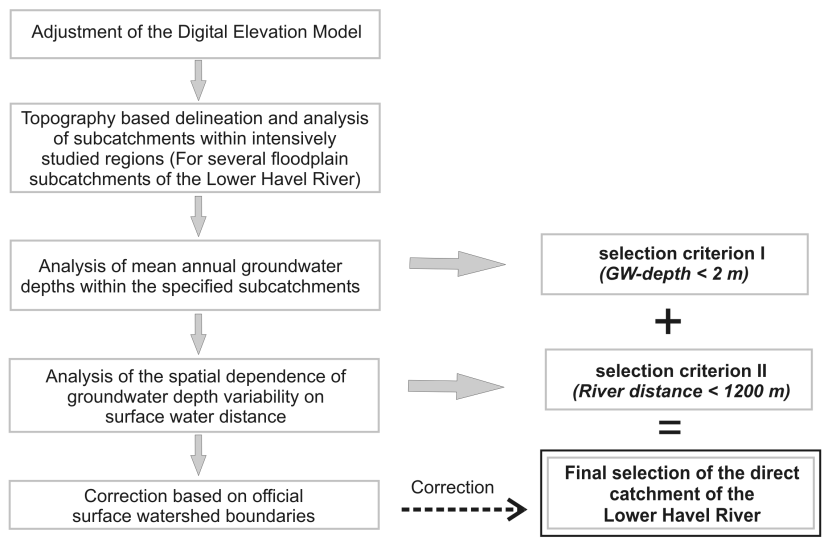

Fig. 3. Delineation algorithm for spatial specification of the "Direct Catchment" extent as part of the Lower Havel River floodplain.

the identification of areas characterised by higher groundwater depths and less influence of surface water stage dynamics. An analysis of the mean annual groundwater depths within the surface watersheds, specified within step two, detected that more than $95 \%$ of the area is characterised by groundwater depths less than $2 \mathrm{~m}$ (Fig. 4). Assuming that areas above this value are not only characterised by higher groundwater stages but also by less interaction to the surface water, a threshold of max. $2 \mathrm{~m}$ groundwater depth was chosen as the first selection criterion to delineate the area of direct interaction between groundwater and surface water.

A map of interpolated observed groundwater depths at the entire Havel River basin was used for spatial intersection of the areas which fulfil this first criterion. Data for this map were originated from observations of the environmental agency of the country Brandenburg (LUA) as well as from own measurements. Within a third step this intersection resulted in a selection of areas which were located in the direct neighbourhood of the Havel River, but also areas which are hydraulically unconnected with the Havel River were captured. Hence, in a fourth step, an additional selection criterion was established. This criterion was based on the dependence of seasonal groundwater stage variability on the intensity of the groundwater - surface water - interactions which is determined by the river distance. Therefore results from previous water balance simulations using the IWAN model within the intensively investigated areas (Krause, 2004c) were analysed.

Water balance simulations within these subcatchments show a strong decrease of simulated seasonal groundwater stage variability within a mean river distance of $1200 \mathrm{~m}$ and prove the cause of these effects by the influence of the river stage dynamics (Krause, 2004a). Thus, as a second selection criterion a $1200 \mathrm{~m}$ buffer zone along the river was chosen for the specification of the direct catchment extent (Fig. 3). After intersection of the buffer strip the selected boundaries of the direct catchment have been furthermore corrected due to the consideration of artificial drainage structures. The implementation of these artificial structures represents a control of

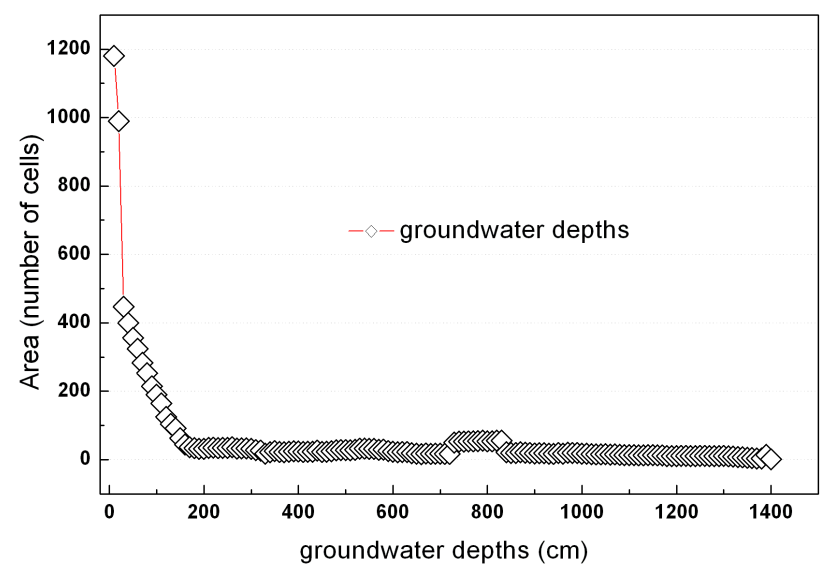

Fig. 4. Distribution of mean annual groundwater depths within delineated intensively investigated subcatchments of the Havel River.

the consistency of the assumption concerning the catchment boundaries which is necessary to ensure adequate reflection of model boundary conditions. In a last step the selected boundaries were additionally verified by the comparison with surface subwatershed boundaries provided by the LUA.

\section{Results and discussion}

The $998.1 \mathrm{~km}^{2}$ "Direct Catchment" finally specified is presented in Fig. 5. For the analysis of water balance characteristics within the "Direct Catchment" and of the mutual impacts of groundwater and surface water, a 12 years period (01.01.1988-31.12.1999) was simulated using the IWAN model. For the characterisation of the atmospheric and the river boundary conditions measured values were used. Figure 6 shows the simulated groundwater recharge, consisting of percolated precipitation water as well as of infiltration from the river, for the entire "Direct Catchment".

Intensive dynamics of alternating groundwater recharge and groundwater discharge periods are obvious. The simulation results show a seasonal periodicity with groundwater recharge during winter and groundwater discharge during summer. Groundwater recharge dynamics between several years differ intensively.

While in the beginning and in the end of the simulation period groundwater recharge varies significantly, the period from 1995 to 1998 is relatively balanced. Analysing the in- and outflows from groundwater to the surface water and vice versa dynamics similar to the dynamics of groundwater recharge can be observed (Fig. 7).

In addition the in- and outflows vary in a seasonal periodicity. Groundwater usually feeds the river during summer. During winter mostly surface water infiltration to the groundwater occurs. Although groundwater exfiltration during summer is relatively balanced, the surface water infiltration during winter varies more intensively between singular years. Comparing the dynamics of groundwater recharge/discharge periods with the dynamics of groundwater exfiltration and 


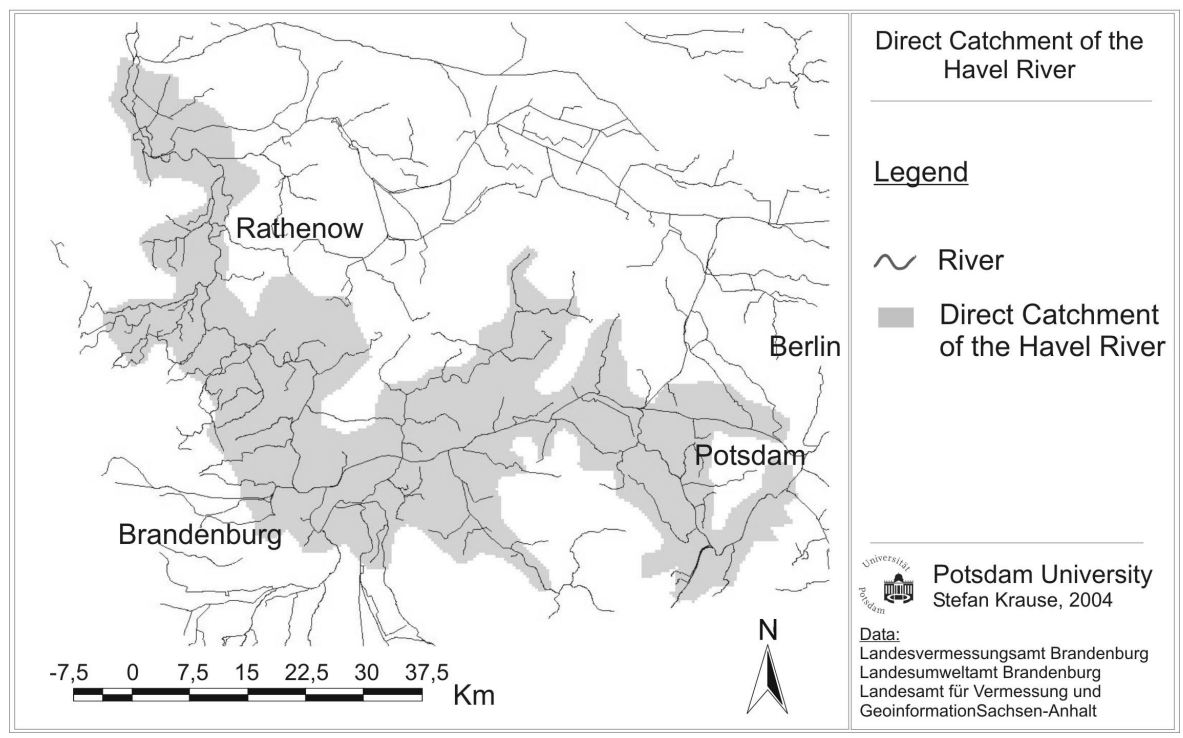

Fig. 5. Specified $998.1 \mathrm{~km}^{2}$ "Direct Catchment" of the Havel River basin.

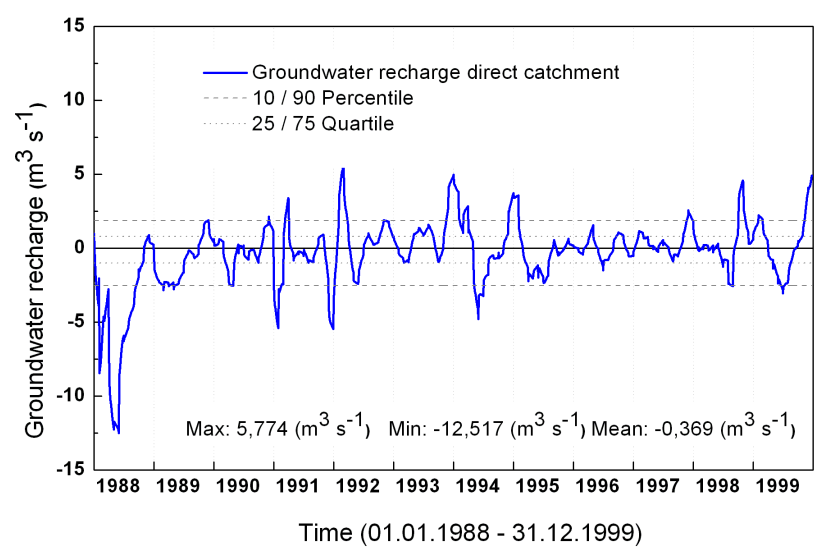

Fig. 6. Simulated groundwater recharge of the "Direct Catchment" for the period 1988-1999 (groundwater recharge is characterised by positive values, groundwater discharge by negative values).

surface water infiltration it is obvious that the dynamics of groundwater recharge are mainly influenced by the interactions between the river and the groundwater. These results are supported by previous studies of smaller subcatchments of the Havel River which also prove the major importance of groundwater - surface water - interactions for the floodplain water balance (Krause, 2004a, c).

Additionally, when analysing the proportion of the groundwater exfiltration of the total amount of runoff which is generated between upstream and downstream gauges (including also the inflows from tributaries) the importance of the interactions between river and adjacent floodplain becomes more clear. As presented in Fig. 8, the mean annual variability (averaged over entire simulation period) of the fraction of groundwater exfiltration from the "Direct Catchment" on the total discharge is characterised by relatively

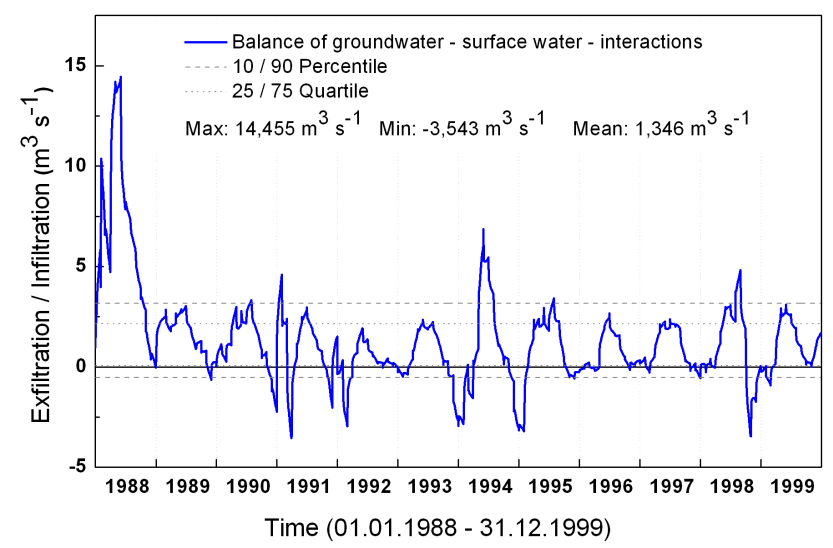

Fig. 7. Simulated interaction between groundwater and surface water for the simulation period 1988-1999 (positive values represent groundwater exfiltration to surface water, negative values surface water infiltration to groundwater).

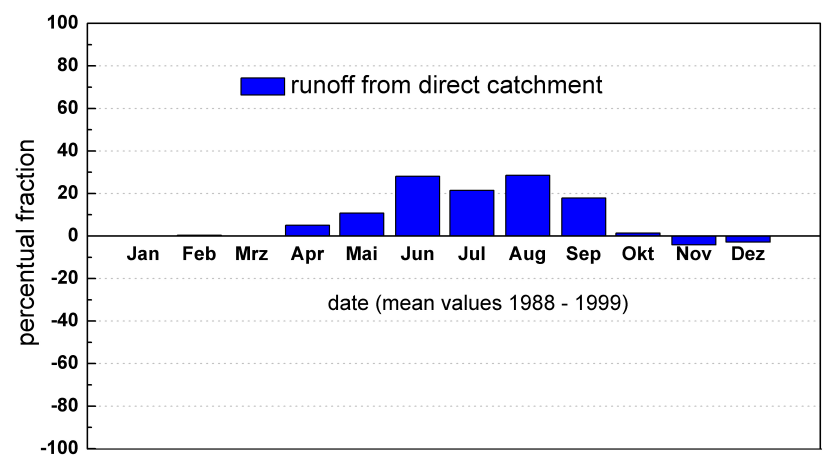

Fig. 8. Temporal dynamics of the runoff fraction generated within the direct catchment on the total discharge of the Havel River. 
balanced conditions between groundwater exfiltration and surface water infiltration from autumn to spring.

The fraction of groundwater supply from "Direct Catchment" on total river discharge is relatively unimportant during this period. In contrast, groundwater exfiltration contributes with up to $30 \%$ on the total discharge of the Havel River during summer. Considering the low discharges of the Havel River during summer, the high ecological and hydrological importance of the groundwater contributions to the river discharge at this period is obvious.

\section{Summary}

By applying the presented delineation algorithm to the floodplain of the Lower Havel River the "Direct Catchment", which is characterised as the interaction zone between river and floodplain, could be specified. Due to the specification of this spatially discrete zone by the maximal extent of the most important processes on floodplain water balance, a correct definition of boundary characteristics and adequate modelling of water balance within the floodplain became possible. The application of the IWAN model allowed the analysis of the dynamics of groundwater recharge and groundwater discharge periods. It furthermore proved the mutual impact of interactions between surface water and groundwater which cause groundwater exfiltration to the river as well as surface water infiltration to the groundwater in a seasonal periodicity. It could be shown that groundwater dynamics and also the water balance of the floodplain are mainly affected by the impact of groundwater - surface water - interactions respectively. An analysis of the impact of these interactions on the river discharge has shown that the most important impact occurs during low discharge periods in summer when groundwater supply produces up to $30 \%$ of the total discharge.

Edited by: P. Krause, K. Bongartz, and W.-A. Flügel

Reviewed by: anonymous referees

\section{References}

Chiang, W. H. and Kinzelbach, W.: 3D-Groundwater Modeling with PMWIN - a Simulation System for Modeling Groundwater Flow and Pollution, Springer-Verlag Berlin Heidelberg New York, 346 p., 2001.

Harbaugh, A. W. and Mc Donald, M. G.: User's documentation for MODFLOW-96, an update to the U.S. Geological Survey modular finite-difference groundwater flow model: USGS Open-File Report 96-485, 1996a.

Harbaugh, A. W. and Mc Donald, M. G.: Programmer's documentation for MODFLOW 96, an update to the U.S. Geological Survey modular finite-difference ground-water flow model: USGS Open-File Report 96-486, 1996 b.

Krause, S. and Bronstert, A.: Wasserhaushaltssimulationen unter Einbeziehung von Grundwasser - Oberflächenwasser - Kopplung zur Optimierung szenarienbasierter Handlungsoptionen für ein nachhaltiges Flussgebietsmanagement an der Unteren Havel, in: Neue Methodische Ansätze zur Modellierung der Wasser- und Stoffumsätze in großen Einzugsgebieten, edited by: Ludwig, R., Reichert, D., Mauser W., Kassel University Press, 61-74, 2004a.

Krause, S., Bauer, A., Morgner, M., and Bronstert, A.: Wasserhaushaltsmodellierung als Beitrag zur Erstellung eines nachhaltigen Flussgebietsmanagements an der Unteren Havel, Forum für Hydrologie und Wasserbewirtschaftung, 05.04, 2, 123-128, 2004b.

Krause, S. and Bronstert, A.: Approximation of Groundwater - Surface Water - Interactions in a Mesoscale Lowland River Catchment, in: Hydrology: Science \& Practice for the 21st Century, British Hydrological Society, 2, 408-415, 2004c.

Niehoff, D.: Modellierung des Einflusses der Landnutzung auf die Hochwasserentstehung in der Mesoskala, Brandenbg. Umweltberichte, Heft 11, 144 p., 2002.

Schulla, J.: Hydrologische Modellierung von Flussgebieten zur Abschätzung von Folgen der Klimaänderung, Züricher Geographische Schriften, Heft 69, 161 p., 1997.

Sophocleous, M.: Interactions between groundwater and surface water: the state of the science, Hydrogeology Journal, 10, 2, 348 p., 2002. 